\begin{tabular}{|c|c|c|}
\hline 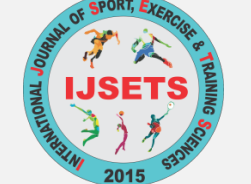 & $\begin{array}{c}\text { INTERNATIONAL JOURNAL OF SPORTS } \\
\text { EXERCISE \& TRAINING SCIENCES } \\
\underline{\text { http://dergipark.gov.tr/useeabd }}\end{array}$ & 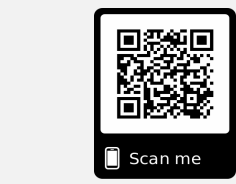 \\
\hline e-ISSN 2149-8229 & Vol 4, Issue 1, 19-25, (2018) & Original Article \\
\hline
\end{tabular}

\title{
The Study of The Somatotypes of the Turkish National Rafting Team
}

\author{
Vedat Ayan ${ }^{1}$, Selami Yüksek ${ }^{2}$, Fatih Bektaş ${ }^{3}$, Fatih Gür ${ }^{4}$, Burak Kural ${ }^{5}$
}

\begin{tabular}{|c|c|}
\hline Abstract & Keywords \\
\hline Aim: In the study, it was aimed to determine the somatotype characteristics of the male athletes & Anthropometry \\
\hline of the Turkish National Rafting Team. 8 male rafting athletes from the Turkish National Rafting & Athlete \\
\hline Team voluntarily participated in the study during the national team camp in Rize before 2015 & Performance \\
\hline World Rafting Champs-Indonesia. & Rafting \\
\hline $\begin{array}{l}\text { Material and Methods: The age, height, weight, skinfold thickness, circumference, and width } \\
\text { measurements of the athletes participated in the study were taken at the Performance Lab of }\end{array}$ & Somatotype \\
\hline $\begin{array}{l}\text { Physical Education and Sports Academy, Karadeniz Technical University. Heath-Carter } \\
\text { method was used to determine their somatotypes. The statistical analyses of the measurements } \\
\text { were carried out by using SPSS } 13 \text {. }\end{array}$ & \\
\hline Results: The mean values of the participant male rafting athletes of the Turkish National & \\
\hline Rafting Team $(\mathrm{n}=8)$ were found as follows; mean age 21 years old; mean height $175.68 \pm 3.32$ & Article Info \\
\hline ; mean body weight $/ 6.001 / .96 \mathrm{~kg}$. The mean values of the somatotype components & Received: 28.07 .2017 \\
\hline & Accepted: 06.03 .2018 \\
\hline $\begin{array}{l}\text { Although there are various studies on determining somatotype characteristics in Sports Science, } \\
\text { those related to rafting are limited in number. }\end{array}$ & Online Published: 15.03.2018 \\
\hline $\begin{array}{l}\text { Conclusion: We are of the opinion that our study, in addition to determining the somatotype } \\
\text { characteristics of the male rafting athletes of the Turkish National Rafting Team, will also } \\
\text { contribute to the studies carried out in this field. }\end{array}$ & DOI: $10.18826 /$ useeabd. 331614 \\
\hline
\end{tabular}

\section{INTRODUCTION}

Anthropometry in general: is a systematic technique which sizes the objective characteristics of the human body with principles and classifies the certain methods of measuring according to the structure (Maud \& Foster, 2006; Ozer, 1993). In other words, Anthropometry is a metric evaluation of individual's body features (Ackland, Ong, Kerr \& Ridge, 2003; Akin \& Sagir, 2000).

The research based on anthropometric features, it has been aimed to find out which body profile suits which branch and thus the selection of the athletes suitable for these profiles are made during the talent selection process (De Garay, Levine \& Carter, 1974; Sogut, Muniroglu \& Deliceoglu, 2004). The ratio of the length, width and circumference of the body parts determine who will be more advantageous in terms of mechanics during sportive activities (Fry \& Morton, 1991; Tahillioglu, Sevim, Pulur \& Alpkaya, 2000).

For many years, the appropriate body type has been considered to play an important role in sport performance. The studies reveal significant differences between the body types of the athletes engaged in different sport branches. However, body size, proportion, body composition are important factors that affect physical performance (Carter, 1984; Maud \& Foster, 1995).

Anthropometric data are useful because some anthropometric variables are correlated with performance (Fry \& Morton, 1991; Van Someren \& Palmer, 2003). Somatotype is the identification of the human body in terms of ectomorphy, mesomorphy and ectomorphy by using scientific methods. (Maud \& Foster, 1995; Ozer, 1993).

Somatic classification or determining the body type is the concern of somatotype. When the literature was examined, no research was found on rafting sport and somatotype. The determination of somatotype structures of athletes at the national team level may play a decisive role in talent selection and training programs. Therefore, this study aimed to determine the somatotype characteristics of the Turkish National Rafting Team.

\footnotetext{
The role and contributions of each authors as in the section of IJSETS Writing Rules "Criteria for Authorship" is reported that: 1. Author: Contributions to the conception or design of the paper, data collection, 2. Author: Data collection, preparation of the paper according to rules of the journal, final approval of the version to be published paper, 3. Author: Contributions to the conception or design of the paper and final approval of the version to be published paper. 4. Author: Data collection, preparation of the paper according to rules of the journal, 5. Author: Contributions to the conception or design of the paper, data collection.

${ }_{1}^{1}$ Corresponding Author: University of Karadeniz Technical, Faculty of Sport Science, Trabzon/Turkey. vayan@ktu.edu.tr ORCID ID: 0000-0003-1887-5334

${ }^{2}$ University of Karadeniz Technical, Faculty of Sport Science, Trabzon/Turkey. selami.yuksek@ktu.edu.tr ORCID ID: 0000-0002-2162-8660

${ }^{3}$ University of Karadeniz Technical, Faculty of Sport Science, Trabzon/Turkey. fatihbektas@ktu.edu.tr ORCID ID: 0000-0002-4569-4662

${ }^{4}$ University of Karadeniz Technical, Faculty of Sport Science, Trabzon/Turkey. fatihgur@ktu.edu.tr ORCID ID: 0000-0003-0776-5754

${ }^{5}$ University of Karadeniz Technical, Faculty of Sport Science, Trabzon/Turkey burakkural@ktu.edu.tr ORCID ID: 0000-0002-0678-0189
} 


\section{METHOD}

\section{Participants}

8 male rafting athletes from the Turkish National Rafting Team (mean age 21) voluntarily participated in the study during the national team camp in Rize before 2015 World Rafting Champs-Indonesia.

Ethical Considerations: Participants were taken from the general health check in an appropriate health facility before the measurements. Participants were informed about the aim and content of the study, and written informed consent was obtained from each subject before initiating any research procedures. The participants were assured of their right to refuse to participate or to withdraw from the study at any time. Anonymity and confidentiality of patient data were guaranteed.

\section{Inclusion Criteria}

- Be a national team sportsman

- Have participated in at least 10 competitions in the national team.

- No acute or chronic illness in terms of general health status.

Design and protocol: The aim of this descriptive study was to determine the somatotype characteristics of the Turkish National Rafting Team.

In our study body weight, height, skin fold thickness (biceps, triceps, subscapula, suprailiac, calf) measurements, the circumference (biceps, calf) and width measurements (elbow, knee) were taken. In our study Heath-Carter method was used to determine the somatotypes of the athletes (Carter \& Heath, 1990).

The following equations were uses for calculating somatotype.

Heath-Carter Somatotype Formula

Endomorph $=-0.7182+0.1451 * \mathrm{x}-0.00068 * \mathrm{x}^{2}+0.0000014 * \mathrm{x}^{3}(\mathrm{x}=$ "triceps" + "subscapula" + "suprailiac")

Height Adjustment Formula $=\mathrm{x} * 170.18 /$ height $(\mathrm{cm})$

Mesomorph $=[0.858+0.601 *$ elbow width -"bicondylar humerus" $(\mathrm{cm})+0.601 *$ width of the knee "bicondylar femur" $(\mathrm{cm})+0.188 *$ arm circumference $(\mathrm{cm})+0.161 *$ calf circumference $(\mathrm{cm})]-[\operatorname{size}(\mathrm{m}) * 0131]+4: 50$

Ectomorph $=($ height - weight ratio $) * 0.732-28.58$ (height-weight ratio $=$ Length $/ 3 \sqrt{\text { Weight }})$

The following formula was used to find the $\mathrm{X}$ and $\mathrm{Y}$ coordinates on the somato-chart

$$
\begin{aligned}
& \mathrm{X}=\text { Ectomorph }- \text { Endomorph } \\
& \mathrm{Y}=2 \times \mathrm{x} \text { Mesomorphic }- \text { (Endomorph }+ \text { Ectomorph) }
\end{aligned}
$$

The somatotype is determined by checking the $\mathrm{X}$ and $\mathrm{Y}$ coordinate on somato-chart (Carter \& Heath, 1990).

\section{Data Collection}

The anthropometric measurements of the athletes in the sample group were taken in accordance with the accredited techniques by "International Biological Programme (IBP)" (Carter \& Heath, 1990; Lohman, Roche \& Martorel, 1988) and "International Society for the Advancement of Kinanthropometry (ISAK)" (Diafas, Dimakopoulou, Diamanti, Zelioti, Kaloupsis, 2011; Ross \& Marfell-Jones 1991). These measurements were carried out by one-trained investigators using standardized procedures. The person responsible for assessment had 3 years experience in this type of procedure. Instruments were calibrated prior to use and all variables except body mass and height measurements were taken on the subject's right side. Every measurement was taken three times by the same person, and the mean value was used for calculation. All anthropometric measurements were taken in the morning (08:00-11:00 hours).

Weight was measured to the nearest $0.1 \mathrm{~kg}$ in light clothes without footwear using a digital scale (Seca, Birmingham, UK). Height was measured with as stadiometer to the nearest $1 \mathrm{~mm}$. Widths and diameters of body parts were measured by using sliding calliper. Circumferences were measured with a non-elastic tape to the nearest $1 \mathrm{~mm}$. lengths were taken with the steel tape to the nearest $0.5 \mathrm{~cm}$. Skinfold thickness measurements were taken with a Lafayette calliper (Lafayette Instrument Company, Lafayette, IN, USA). Body density (BD) was estimated using the method of Jackson and Pollock (Jackson \& Pollock, 1978). BD was transformed to \%BF by the Brozek's equation (Brozek, Grande, 
Anderson \& Keys, 1963). Height-adjusted endomorph values were used and the somatotypes were plotted on a two-dimensional grid system somato-chart using the appropriate software (Somatotype 1.2 software).

\section{Statistical Analysis}

Arithmetic mean and the standard deviations of all measurements taken were calculated. SPSS 13,0 program was used for the statistical analysis of the measurements. Using the following equations (with standard formulations) somatotype values were calculated.

\section{RESULTS}

In our study, the Turkish National Rafting Team athletes' $(\mathrm{n}=8)$ mean weight and height were found as $76.00 \pm 7.96 \mathrm{~kg}$ and $175.68 \pm 3.32 \mathrm{~cm}$ respectively. When the triceps-one of the measurements used to determine body fat amount- was examined, triceps skinfold thickness was found as $6.75 \pm 3.05 \mathrm{~mm}$. When the values of suprailiac and subscapular skinfold thicknesses (these sites are located in the center of the body and reflect the amount of fat in the centre) were examined, the former was found as $6.65 \pm 3.25 \mathrm{~mm}$ and the latter was found as $10.22 \pm 2.24 \mathrm{~mm}$. In our study, the value of Calf skinfold thickness was found as $11.51 \pm 8.41 \mathrm{~mm}$. Of the examined anthropometric variables, biceps and calf circumference were found as $32.50 \pm 2.12 \mathrm{~cm}$, and $35.40 \pm 2.11 \mathrm{~cm}$ respectively. The elbow and knee width values- of the anthropometric measurements carried out in our study- were as $6.95 \pm 0.29 \mathrm{~cm}$ and as $10.15 \pm 0.42 \mathrm{~cm}$ respectively (Table 1).

Table 1. The Mean and Standard Deviation Values of the Anthropometric Measurements of the male rafting athletes of the Turkish National Rafting Team.

\begin{tabular}{lc}
\hline \multicolumn{1}{c}{ Parameters $(\mathbf{N}=\mathbf{8})$} & Mean \pm SD \\
\hline Weight $(\mathrm{kg})$ & $76.00 \pm 7.96$ \\
Height $(\mathrm{cm})$ & $175.68 \pm 3.32$ \\
Triceps skinfold thickness $(\mathrm{mm})$ & $6.75 \pm 3.05$ \\
Subscapula skinfold thickness $(\mathrm{mm})$ & $10.22 \pm 2.24$ \\
Suprailiac skinfold thickness $(\mathrm{mm})$ & $6.65 \pm 3.25$ \\
Calf skinfold thickness $(\mathrm{mm})$ & $11.51 \pm 8.41$ \\
Biceps circumference $(\mathrm{cm})$ & $32.50 \pm 2.12$ \\
Calf circumference $(\mathrm{cm})$ & $35.40 \pm 2.11$ \\
Elbow width $(\mathrm{cm})$ & $6.95 \pm 0.29$ \\
Knee width $(\mathrm{cm})$ & $10.15 \pm 0.42$ \\
Endomorph & $2.23 \pm 0.88$ \\
Mesomorph & $5.04 \pm 0.91$ \\
Ectomorph & $1.92 \pm 0.94$ \\
\hline
\end{tabular}

Individual somatotype values of the male rafting athletes of the Turkish National Rafting Team participated in our study are given in Table 2 .

Table 2. The Somatotype values of the male rafting athletes of the Turkish National Rafting Team.

\begin{tabular}{cccc}
\hline Athletes & Endomorph & Mesomorph & Ectomorph \\
\hline $\mathbf{1}$ & 2.38 & 5.60 & 1.41 \\
$\mathbf{2}$ & 2.39 & 4.58 & 1.62 \\
$\mathbf{3}$ & 1.43 & 3.93 & 3.21 \\
$\mathbf{4}$ & 2.88 & 6.45 & 0.91 \\
$\mathbf{5}$ & 1.35 & 5.50 & 2.07 \\
$\mathbf{6}$ & 3.87 & 5.48 & 0.89 \\
$\mathbf{7}$ & 1.30 & 3.75 & 3.39 \\
$\mathbf{8}$ & 2.24 & 5.07 & 1.92 \\
\hline
\end{tabular}




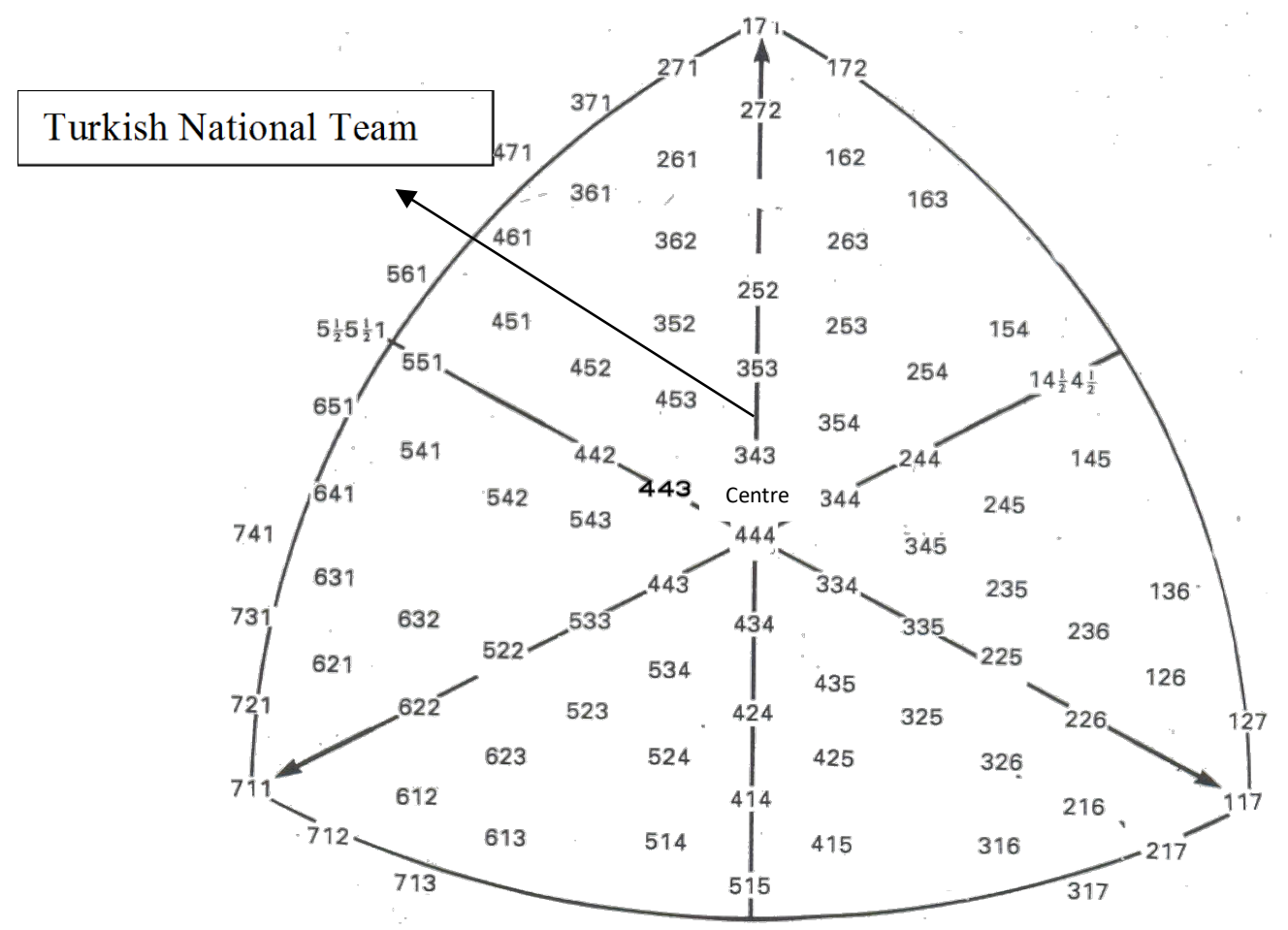

Figure 1. The distribution of the Turkish National Male Rafting Team Paddlers' mean somatotype on the somato-chart.

The Distribution of the Turkish National Male Rafting Team Paddlers' average somatotype on the somato-chart according to the data obtained from this study is shown in figure 1 .

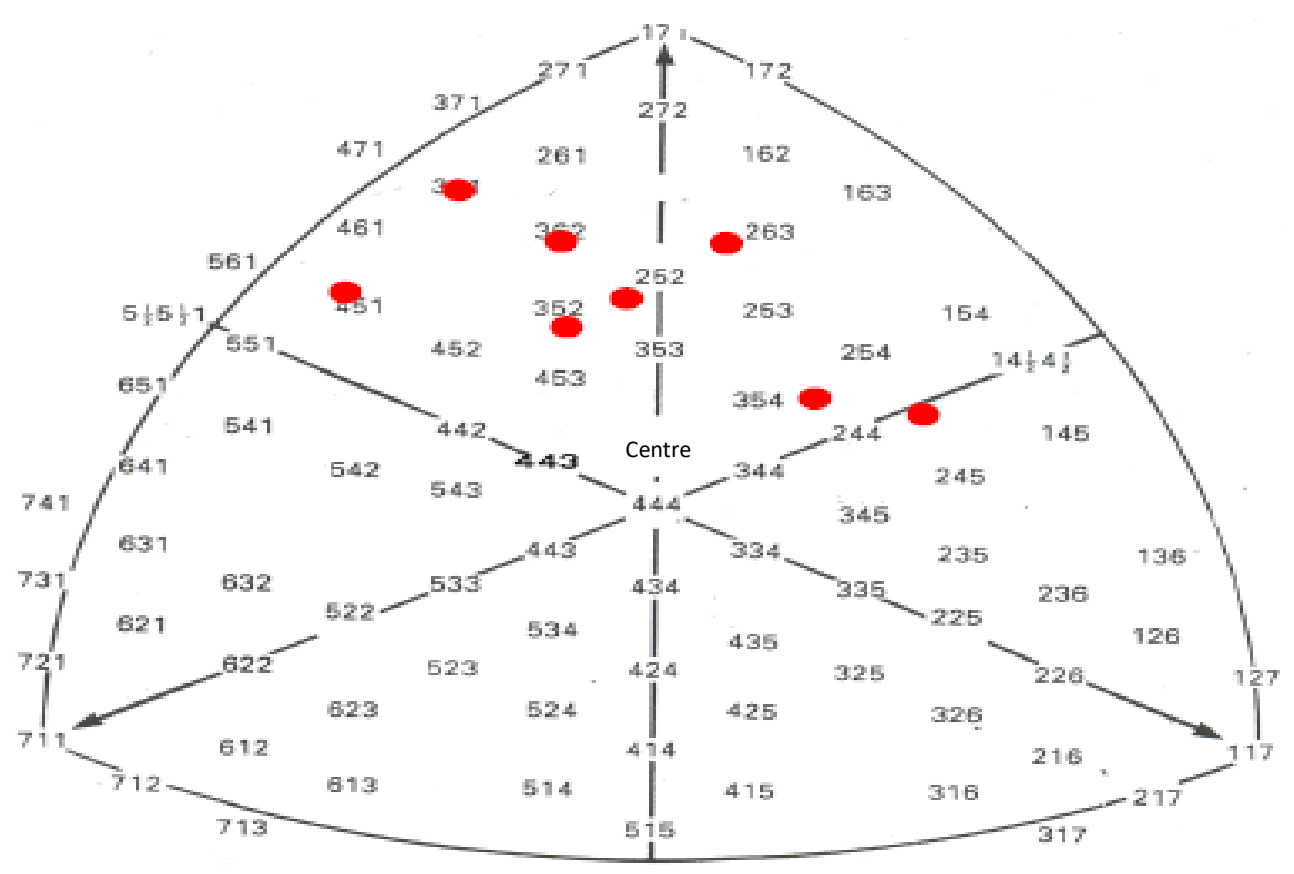

Figure 2. The Distribution of the Turkish National Male Rafting Team Paddlers' Somatotypes on the somatochart. 
Distributions of the 8 Turkish National Male Rafting Team Paddlers' Somatotypes on the somatochart according to the data obtained from this study are seen in figure 2.

\section{DISCUSSION}

The goal in all branches of sports achieves success. The scientific researches which are increasing more in our country, have a positive influence on success. It has been shown that the structural characteristics of the body have a tendency to differentiate in various sport branches and different categories of the same sport branches. The data obtained is important in terms of; being a guidance to the sport branches for athletes; education of the young athletes; the training and improvement of performance of the elite level athletes. Therefore, the determinations of the morphological and physiological structures of the athletes are crucial (Akin \& Sagir, 2000; Alacid, Marfell-Jones, López-Miñarro, Martínez \& Muyor, 2011; Diafas et al., 2011; Ridge, Broad, Kerr \& Ackland, 2007; Carter \&Heath 1990; Ross \& MarfellJones, 1991; Heyward \& Stolarczy, 1996; Zorba \& Ziyagil, 1995).

Therefore, the anthropometric measurements taken in early periods of the athlete's sport training (height, body weight, length measurements etc.) are important.

Our study carried out in accordance with this objective recruited the Turkish National Male Rafting Team Paddlers' and determined their somatotypes.

Anthropometric data available for male and female, elite sprint canoe/kayak paddlers suggest a homogenous shape and size (Ackland et al., 2003). Ackland et al. noted that sprint kayak paddlers possess unique characteristics, which not commonly observed in the general population. These include a lean body composition with proportionately large upper body girths and narrow hips (for males). The mean somatotype recorded for males by Ackland et al. was 1.6-5.7-2.2 and demonstrated that canoe paddlers are best described as mesomorphs. Ackland et al. 50 males and 20 females sprint canoeists/skiers were assessed in Sydney Olympic Games, which represented 9 countries.

Sydney Olympic paddlers compared to paddlers represented at the Montreal Olympics in 1976, were approximately five kilograms heavier on average. However, with comparable skin fold values for the two groups, it was suggested by Ackland et al. (2003) that the subjects in the present sample have a higher proportion of lean body mass. Therefore, it was speculated by Ackland et al. that the morphology of elite paddlers has altered during the past 25 years and shifted toward a heavier but more lean physique.

Alacid et al. (2011) in their studies found the mean somatotype for 13-year-old male paddlers as 2.7-4.8-3.1 and 14-year-old male paddlers as 2.6-4.6-3.1 and described them as balanced mesomorphs.

The young male paddlers (mean somatotype for 13-year-old male paddlers 2.7-4.8-3.1 and mean somatotype for 14-year-old male paddlers 2.6-4.6-3.1) participated in the study of Alacid et al. (2011) were less lean, less robust musculoskeletal and less compact than Olympic sprint 1.6-5.7-2.2 and slalom 1.7-5.4-2.5 paddlers.

When the canoe and somatotype studies in literature are examined, canoe athletes have mesomorphic or endomorphic mesomorphic structure;

In the study of Diafas et al. (2011) men skiers who participated in their study are best described as endomorphic-mesomorph. Carter, Ross, Aubry, Hebbelink \& Borms. (1982) found the somatotype of the male canoeists paddlers who participated in the Montreal Oliympics as 1.5-5.2-3.1. De Garay et al. (1974) in their studies found the mean somatotype of the canoe paddlers who participated in 1968 Mexico City Olympics as 1.9-5.5-2.5. Stepnicka, Chytrackova, Kasalicka \& Kubrychtova (1979) in his study found the mean somatotype of the Czechoslovakian speed canoe paddlers as 2.0-5.8-2.1. Stepnicka et al. in their studies found the mean somatotype of the slalom canoe paddlers as 2.1-5.7-2.3. Meszaros \& Mohacsi (1982) in their studies found the mean somatotype of the Hungarian canoe paddlers as 2.2-5.5-2.5. Vaccaro, Gray, Clarke \& Morris (1984) in their studies found the mean somatotype of the American (the USA) slalom canoe paddlers as 2.9-5.2-2.4.

Even though there are researches on different paddlers branches and somatotype structure, no research has been found on rafting branch and somatotype structure in the literature. For this reason, the determination of somatotype structures of rafting athletes at the elite level is important in terms of literature and practitioners. 
In our study the Turkish National Male Rafting Team Paddlers' mean age was $19.10 \pm 2.68$ years old, mean height was $176.20 \pm 5.69 \mathrm{~cm}$, mean body weight was $74.54 \pm 10.71 \mathrm{~kg}$ and values of the mean somatotype were 2.2-5.4-1.9 and they were determined as endomorphic mesomorph.

With the results obtained, somatotype structures of elite rafting athletes were revealed. On the other hand, it has been found that the somatotype structures of different paddlers and rafting athletes are similar.

\section{CONCLUSION}

As a result, it is considered that the studies on somatotypes of the rafting paddlers, who are scarce in our country, will contribute to the literature, and we believe that performing such studies on larger study groups and on athletes from different branches will bring better results as well.

On the other hand, knowing the somatotype structure of national team athletes will help trainers determine talent selection criteria and training programs.

Working with a single national team and one age group in the study is the limitation of this research.

\section{Acknowledgement}

The physical and physiological tests were carried out at the School of Physical Education and Sport at Karadeniz Technical University.

\section{REFERENCES}

Ackland, T.R., Ong, K.B., Kerr, D.A. \& Ridge, B. (2003). Morphological characteristics of Olympic sprint canoe and kayak paddlers. J Sci Med Sport2, 6: 285-94.

Alacid, F., Marfell-Jones, M., López-Miñarro, P.A., Martínez, I. \& Muyor J.M. (2011). Morphological characteristics of young elite paddlers. J Hum Kinetics. 27; 95-110.

Akin, G. \& Sagir, M. (2000). Environmental factors affecting obesity in rural men. Vocational Education Journal, 2(2): 2.

Brozek, J., Grande, F., Anderson, J.T. \& Keys, A. (1963). Densitometric analysis of body composition: Revision of some quantitative assumptions. Ann New York Acad of Sci, 110: 113-140.

Carter, J.E.L., Ross, W.D., Aubry, S.P., Hebbelink, M. \& Borms J. (1982). Anthropometry of Montreal Olympic athletes. Med Sports, 16: 25-52.

Carter, J.E.L. (1984). Somatotypes of olympic athletes from 1984 to1976. In: Physical structure of olympic athletes. Karger Publishers, p. 80-109.

Carter, J.E.L., Heath, B.H. (1990). Somatotyping - development and applications. Vol. 5. Cambridge University Press.

De Garay, A.L., Levine, L. \& Carter, J.E.L. (1974). Genetic and anthropological studies of olympic athletes. NewYork: Academic Press.

Diafas, V., Dimakopoulou, E., Diamanti, V., Zelioti, D. \& Kaloupsis, S. (2011) Anthropometric characteristics and somatotype of Greek male and female flatwater kayak athletes. Biomed Hum Kinetics, 3: $111-114$.

Fry, R.W. \& Morton, A.R. (1991). Physiological and kinanthropometric attributes of elite flatwater kayakers. Med Sci Sports Exercise, 23(11): 1297-1301.

Heyward, V.H. \& Stolarczy L.M. (1996). Applied Body Composition Assessment. USA: Hum Kinetics.

Jackson, A.S. \& Pollock, M.L. (1978). Generalized equations for predicting body density of men. $\mathrm{Br} J$ Nutr, 40(03): 497-504.

Lohman, T.G., Roche, A.F. \& Martorel, R. (1988). Anthropometric standardization reference manual. Illinois: Human Kinetics Books Champaign.

Maud, P.J. \& Foster, C. (1995). Physiological assessment of human fitness, USA: Human Kinetics, pp. 205-215. 
Maud, P.J. \& Foster, C. (2006). Physiological assessment of human fitness. 2nd ed. Champaign, IL: Human Kinetics.

Meszaros, J. \& Mohacsi, J. (1982). The somatotype of Hungarian male and female class 1 paddlers and rowers. Anthropol Közl, 175-9.

Ozer, K. (1993). Antropometri, sporda morfolojik planlama. 1.bask. Ístanbul: Kazancı Matbaacıllk.

Ridge, B., Broad, E., Kerr, D. \& Ackland, T. (2007). Morphological characteristics of Olympic slalom canoe and kayak paddlers. Eur J Sport Sci, 7:107-13.

Ross, W.D. \& Marfell-Jones, M.J. (1991). Physiological testing of the high-performance athlete. Kinanthropometry, Illinois: Human Kinetics Books Champaign, pp:230

Sogut, M., Muniroglu, S. \& Deliceoglu, G. (2004). Anthropometric and somatotype characteristics of young and male tennis players in different categories. Spormetre Journal of Physical Education and Sports Sciences, 2(4): 156.

Stepnicka, J., Chytrackova, J., Kasalicka, V. \& Kubrychtova, I. (1979). Somatic preconditions for study of physical education: (In Czech.) Prague: Universita Karlova.

Tahillioglu, A., Sevim, Y., Pulur, A. \& Alpkaya, U. (2000Determination of anthropometric and somatotype characteristics in swimming. 1. Gazi Physical Education and Sports Science Congress Book, ss: 154 .

Vaccaro, P., Gray, P.R., Clarke, D.H. \& Morris A.F. (1984). Physiological characteristics of world-class white-water slalom paddlers. Res Q for Exerc Sport, 55(2); 206-10.

Van Someren, K.A. \& Palmer, G.S. (2003). Predictor of $200 \mathrm{~m}$ sprint kayaking performance. Appl Physiol Nutr Metab, 28 (4): 505-517.

Vaccaro, P., Gray, P.R., Clarke, D.H. \& Morris A.F. (1984). Physiological characteristics of world-class white-water slalom paddlers. Res Qfor Exerc Sport, 55(2); 206-10.

Zorba, E. \& Ziyagil, M.A. (1995). Body composition and measurement methods. Ankara: Gen Advertising Ltd. Şti, 1995.

\section{CITATION OF THIS ARTICLE}

Ayan, V., Yüksek, S., Bektaş, F., Gür, F., \& Kural, B. (2018) The study of the somatotypes of the Turkish National Rafting Team. Int $J$ Sport Exer \& Train Sci, 4 (1), 19-25. DOI: 10.18826/useeabd.331614 